\title{
Age assignment of the upper Carboniferous Arbasay Formation in Shichang Region, North Tianshan (NW China)
}

\author{
Jia-Lin Wang ${ }^{1}$, Chao-Dong Wu ${ }^{1,2^{*}}, X_{i}$ Jiang $^{1}$, Wen Zhu' ${ }^{1}$, Jun $\mathrm{Wu}^{1}$, Jun Wang ${ }^{3}$ and Meng-Lin Zheng ${ }^{4}$
}

\begin{abstract}
The North Tianshan Orogenic Belt contains the youngest ophiolites in the Tianshan and provides some information on timing of the last closure of the Junggar-Balkhash Ocean. LA-ICP-MS zircon U-Pb dating was conducted to define the formation age of the Arbasay Formation in the Shichang Region of North Tianshan, which is exposed near the suture zone but its age remains debated. The Arbasay Formation is mainly composed of volcanic and volcaniclastic rocks with tuff interlayers. The zircons from the tuffs yield two age populations of $315 \pm 3 \mathrm{Ma}$ and 304 $\pm 2 \mathrm{Ma}$, constraining the commencement and demise timings of volcanism, respectively. Furthermore, zircon $\mathrm{U}-\mathrm{Pb}$ age spectra of the tuffaceous sandstones display the youngest peak age at $308 \mathrm{Ma}$, indicating a $<308 \mathrm{Ma}$ age for the depositional age of volcaniclastic rocks. The volcaniclastic rocks therefore were likely to deposit together with the syn-sedimentary volcanism during Late Carboniferous. This means that the Arbasay Formation in Shichang Region should be re-assigned to Late Carboniferous in age. Given that the Arbasay Formation was likely to be formed during the tectonic transition from compression to extension, the Junggar-Balkhash Ocean possibly closed during Late Carboniferous.
\end{abstract}

Keywords: Xinjiang, LA-ICP-MS zircon U-Pb dating, Stratigraphic age, Volcaniclastic rock, Junggar-Balkhash Ocean

\section{Introduction}

The North Tianshan suture zone, the youngest collisional belt in the Tianshan Orogenic Belt, provides a pivotal upper-age for the last closure of the Junggar-Balkhash Ocean (Filippova et al. 2001; Han et al. 2010; Korobkin and Buslov 2011; Windley et al. 2007). However, the timing for the last closure of the Junggar-Balkhash Ocean has long been controversial (Ge et al. 2015; Han et al. 2010; Tang et al. 2010; Xiao et al. 2008). This ocean may have been closed during the Early-Middle Devonian (Han et al. 1997), or Late Devonian-Early Carboniferous (Gao et al. 1995; Han et al. 2010), or Late Carboniferous (Bykadorov et al. 2003; Wang et al. 2017; Yang et al. 2013), and even Permian

\footnotetext{
* Correspondence: cdwu@pku.edu.cn

${ }^{1}$ Key Laboratory of Orogenic Belts and Crustal Evolution, Ministry of Education, School of Earth and Space Sciences, Peking University, Beijing 100871, China

${ }^{2}$ Institute of Oil \& Gas, Peking University, Beijing 100871, China

Full list of author information is available at the end of the article
}

(Xiao et al. 2008). These varied ages have been derived from petrology and geochemistry of the volcanic rocks (Ge et al. 2015; Liu et al. 2012; Tang et al. 2010; Wang et al. 2017), intermediate to acidic intrusions (Han et al. 2010; Tang et al. 2010; Zhang et al. 2012), and ophiolites (Xu et al. 2005, 2006). So far, no petrologic and geochemical studies have been undertaken on volcaniclastic rocks. Increasing evidence shows that petrology and geochemistry analysis of volcaniclastics is critical for understanding the plate tectonic settings (Manville et al. 2009). In the North Tianshan region, a suite of volcaniclastic rocks intercalated with the volcanic rocks are assigned to the Arbasay Formation (Fig. 1; BGMRXUAR 1993; Liu et al. 2012, 2015). Previously, the Arbasay Formation was interpreted as a continental arc formed in the transition stage from compression to extension (Wang et al. 2017), which restricts the last closure time of the Junggar-Balkhash Ocean (Han et al. 2010), although its age is open for debates (BGMRXUAR 1993, 1999; Liu et al. 2012, 2015; Su et al. 


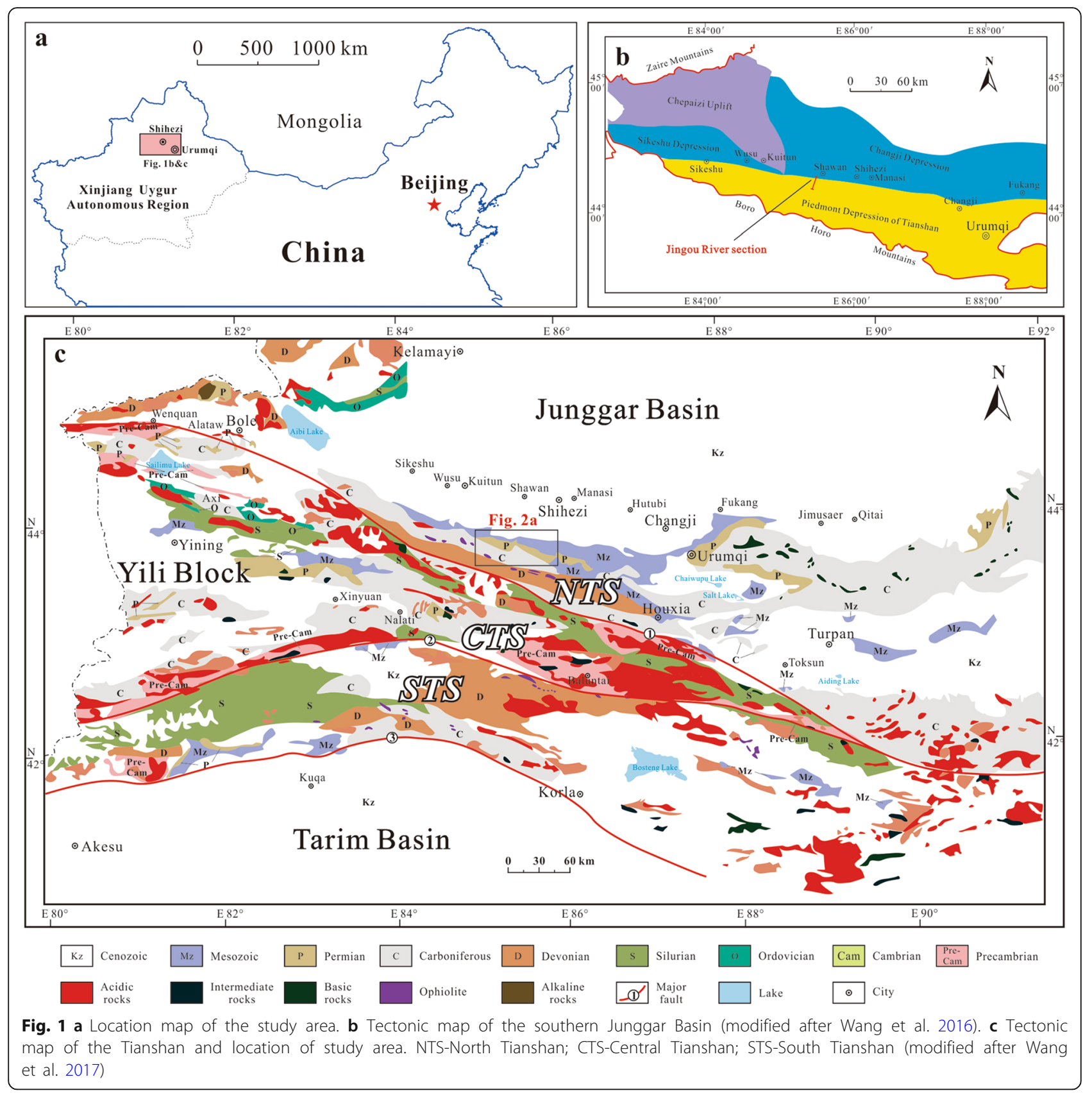

2006a, 2016b; Wang et al. 2017; Yang et al. 2006). The age constraints and correlations of these volcaniclastic strata have long remained unclear due to the paucity of accurate absolute age, the lateral discontinuity of outcrops, and absence of the datable fossils.

In this paper, we report new zircon $\mathrm{U}-\mathrm{Pb}$ ages of the volcaniclastic rocks from the upper part of Arbasay Formation in Shichang Region, northern Xinjiang. Based on these newly obtained ages and previously published data, we examined the era of the Arbasay Formation, and made discussion about the last closure time of the Junggar-Balkhash Ocean.

\section{Geological setting}

The Tianshan tectonic complex, which results from complex accretions of island arcs and amalgamation of continental lithospheric blocks during the late Paleozoic (Carroll et al. 1995; Charvet et al. 2007; Gao et al. 1998; Wang et al. 2007, 2009, 2010), is crucial for understanding the geological evolution of the Central Asia Orogenic Belt (Han et al. 2010; Xiao et al. 2008). This complex is traditionally subdivided into the North Tianshan, Central Tianshan, and South Tianshan orogenic belts (Fig. 1c). The Tarim-South Tianshan and Central Tianshan Blocks collided during the Devonian-Carboniferous (Chen and 
Shi 2003; Han et al. 2011; Wang et al. 2010). This accretion was followed by the collision of the newly formed Tarim-Central Tianshan Blocks with a series of the late Paleozoic island arcs now forming the North Tianshan (Han et al. 2010; Charvet et al. 2011).

The North Tianshan Orogenic Belt is located in south of the Junggar Basin (Fig. 1), and is usually interpreted as a continental arc distributed over the northern part of the Central Tianshan Block since the southward subduction of the paleo-Junggar-Balkhash Ocean during the Paleozoic (Gao et al. 1998; Wang et al. 2007, 2017, 2018). The intermediate-acidic igneous rocks are widely distributed in the North Tianshan Mountain areas (Gao et al. 1998), characteristics of typical calc-alkaline series and continental arc-like geochemical compositions (Wang et al. 2017). Along the northern margin of the North Tianshan, both volcanic and volcaniclastic rocks are widely distributed in the northern areas of the Bayinggou ophiolite belt (Fig. 1). These rocks were primitively assigned to the Lower Permian Arbasay Formation, which is typically exposed in the Jingou River (Fig. 1). The Arbasay Formation unconformably overlies the Upper Carboniferous Qianxia Formation which is characterized by island arc volcanic rocks, and was overlain by the Late Permian-Early Triassic coarse clastic rocks (Figs. 2 and 3). The overlying strata contacted the Arbasay Formation with faults (Figs. 2a and 3). Lithologically, the
Arbasay Formation volcanics show typical basalts-andesites-dacites-rhyolites volcanic series, and are dominated by andesites with minor constituents of basalts and rhyolites (Fig. 2b, c). The volcaniclastic rocks include pink tuff (ignimbrite), greyish volcanic breccia, greyish brown tuffaceous sandstone, and variegated volcanic agglomerate (Figs. 4 and 5). Intermediate-acid and basic igneous rocks dominated the lower part of the Arbasay Formation (Fig. 4a, b, d, e), and andesite and basalt with interbeds of tuff, tuffaceous sandstone, volcanic breccia, and volcanic agglomerate predominated the upper part of the formation (BGMRXUAR 1993; Wang et al. 2017; Figs. 4a, c, f-i and 5). Conspicuously, the lower part of the Arbasay Formation mainly consists of volcanic rocks, while the upper part is principally composed of volcaniclastic rocks with minor volcanic rocks (Fig. 2b, c).

\section{Methods and data}

Zircon grains were separated from the volcaniclastic rocks of the Arbasay Formation for U-Pb dating. They were extracted using heavy-liquid and magnetic techniques, and further purified by hand-picking under a binocular microscope. They were set in an epoxy mount which was polished, and then vacuum-coated with a layer of $50 \mathrm{~nm}$ high-purity gold. Cathodoluminescence (CL) images for zircons were undertaken in order to

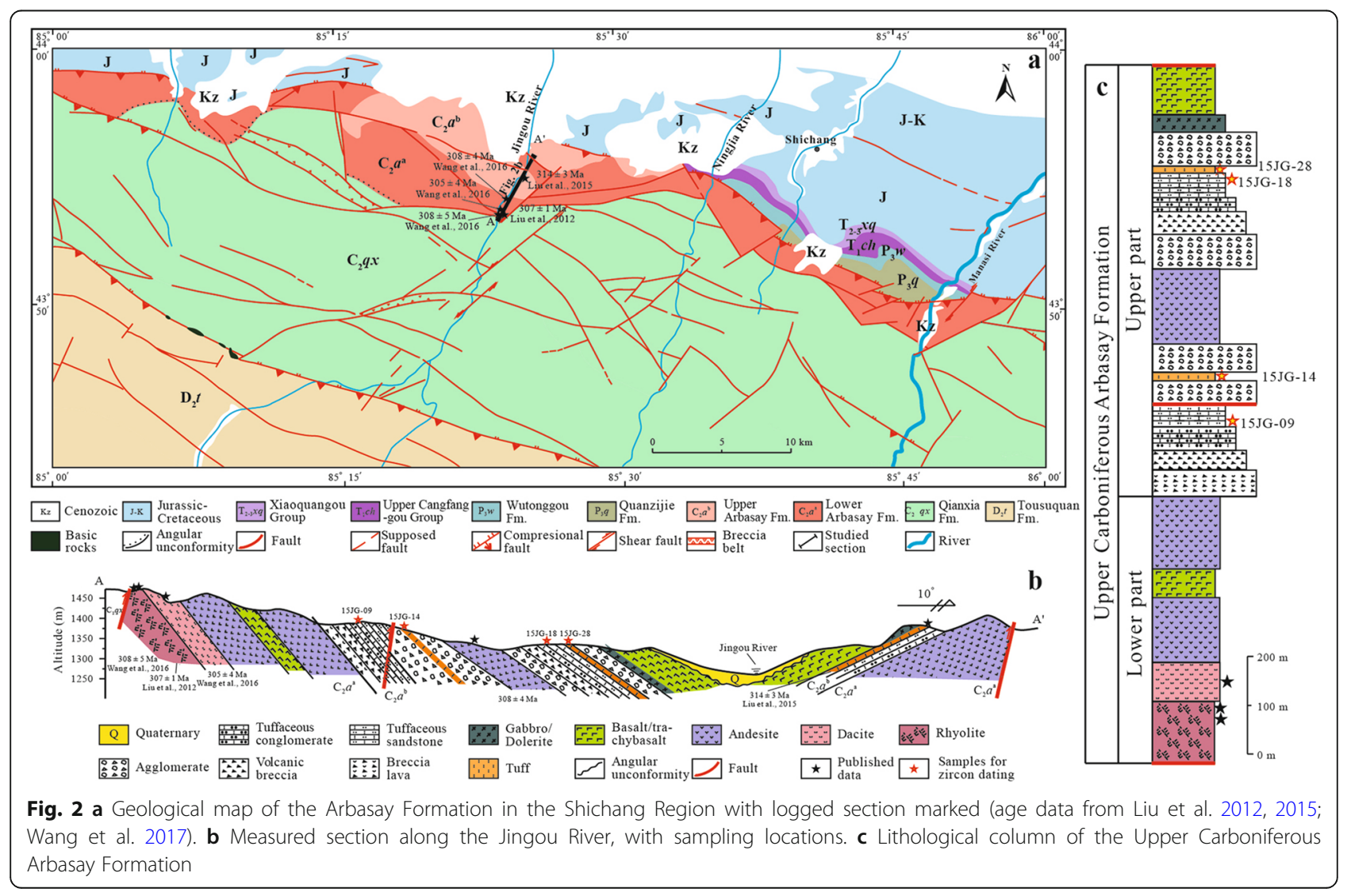




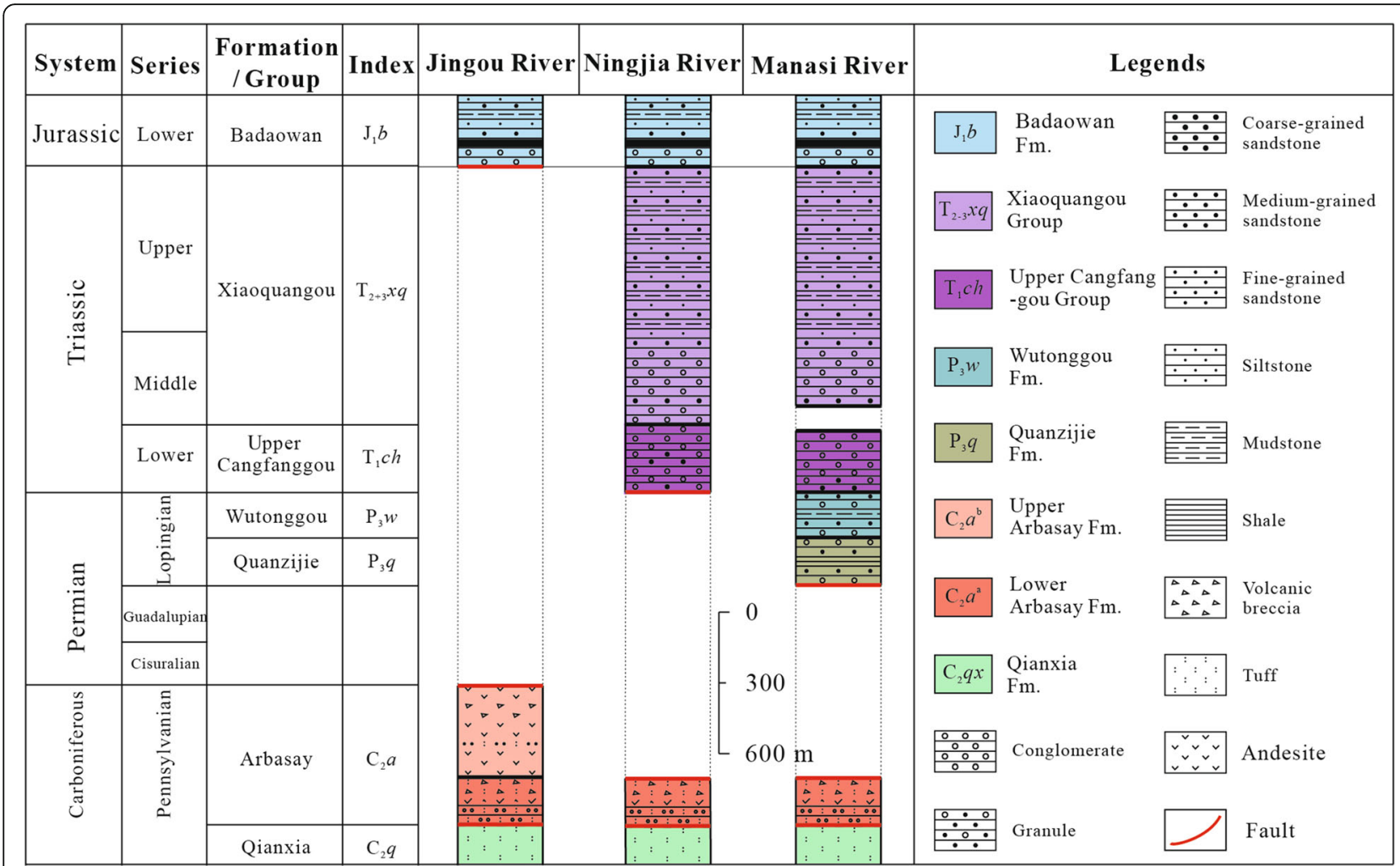

Fig. 3 Comparison of stratigraphic contact relation of the Arbasay Formation in the Shichang Region

examine the internal structure of individual grains. Zircon $\mathrm{LA}-\mathrm{ICP}-\mathrm{MS} \mathrm{U}-\mathrm{Pb}$ isotope analyses were performed at MOE Key Laboratory of Orogenic Belts and Crustal Evolution, School of Earth and Space Sciences, Peking University. Detailed analysis procedures were similar to those described by Yuan et al. (2004). The common lead was corrected using the method of Andersen (2002). The age calculation was finished by ISOPLOT 3 (Ludwig 2003).

\section{Results}

The zircon $\mathrm{U}-\mathrm{Pb}$ analytical results were listed in Additional file 1 and CL images were shown in Fig. 6. Almost all of these zircons are 80-240 $\mu \mathrm{m}$ in size and have euhedral crystals. The CL images show strong oscillatory zoning (Fig. 6), combined with their high $\mathrm{Th} / \mathrm{U}$ ratios (0.36-1.61; Additional file 1), indicative of magmatic origin (Corfu et al. 2003).

Sample 15JG-09 is tuffaceous sandstone obtained from the upper part of Arbasay Formation. 59 analyses of $\mathrm{U}-\mathrm{Pb}$ dates give a range of ${ }^{206} \mathrm{~Pb} /{ }^{238} \mathrm{U}$ ages scattering between 287 and $355 \mathrm{Ma}$ (Additional file 1). ${ }^{206} \mathrm{~Pb} /{ }^{238} \mathrm{U}$ age spectrum exhibits a major peak of $308 \mathrm{Ma}$ which correlates well with the major eruption time of the Arbasay volcanic rocks in the Jingou River (Figs. 7 and 8a; Liu et al. 2012; Wang et al. 2017).
Sample 15JG-14 is a tuff (ignimbrite) derived from the upper part of Arbasay Formation. Total 20 zircons give two ${ }^{206} \mathrm{~Pb} /{ }^{238} \mathrm{U}$ age populations, with a weighted mean age of $304 \pm 2 \mathrm{Ma}(n=13, \mathrm{MSWD}=0.97)$ and $315 \pm$ $3 \mathrm{Ma}(n=5, \mathrm{MSWD}=0.12)$, respectively (Fig. 7).

Sample 15JG-18 from the upper part of Arbasay Formation yields 61 age points with sufficient concordance (Additional file 1). Except for one inherited zircon with age of $387 \pm 4 \mathrm{Ma}$, the rest analyses give ages scattering from $287 \mathrm{Ma}$ to $326 \mathrm{Ma}$. The ${ }^{206} \mathrm{~Pb} /{ }^{238} \mathrm{U}$ age spectrum has a major peak of $308 \mathrm{Ma}$, which was well consistent with the age of contemporaneous volcanism recorded in the Arbasay Formation (Figs. 7 and 8a).

The tuff sample 15JG-28 was collected from the upper part of Arbasay Formationin. Total 20 zircons yield a ${ }^{206} \mathrm{~Pb} /{ }^{238} \mathrm{U}$ weighted mean age of $310 \pm 3 \mathrm{Ma}$ $(\mathrm{MSWD}=2.9)($ Fig. 7$)$, which is interpreted as the depositional age of the formation. Other four zircons have ages ranging from $323 \mathrm{Ma}$ to $333 \mathrm{Ma}$, representing the inherited magmatic zircons from previous volcanic rocks.

\section{Discussion}

\subsection{Age constraint for the Arbasay Formation}

Both LA-ICP-MS and SHRIMP U-Pb zircon dating approaches have been applied to calibrate the age of Arbasay 

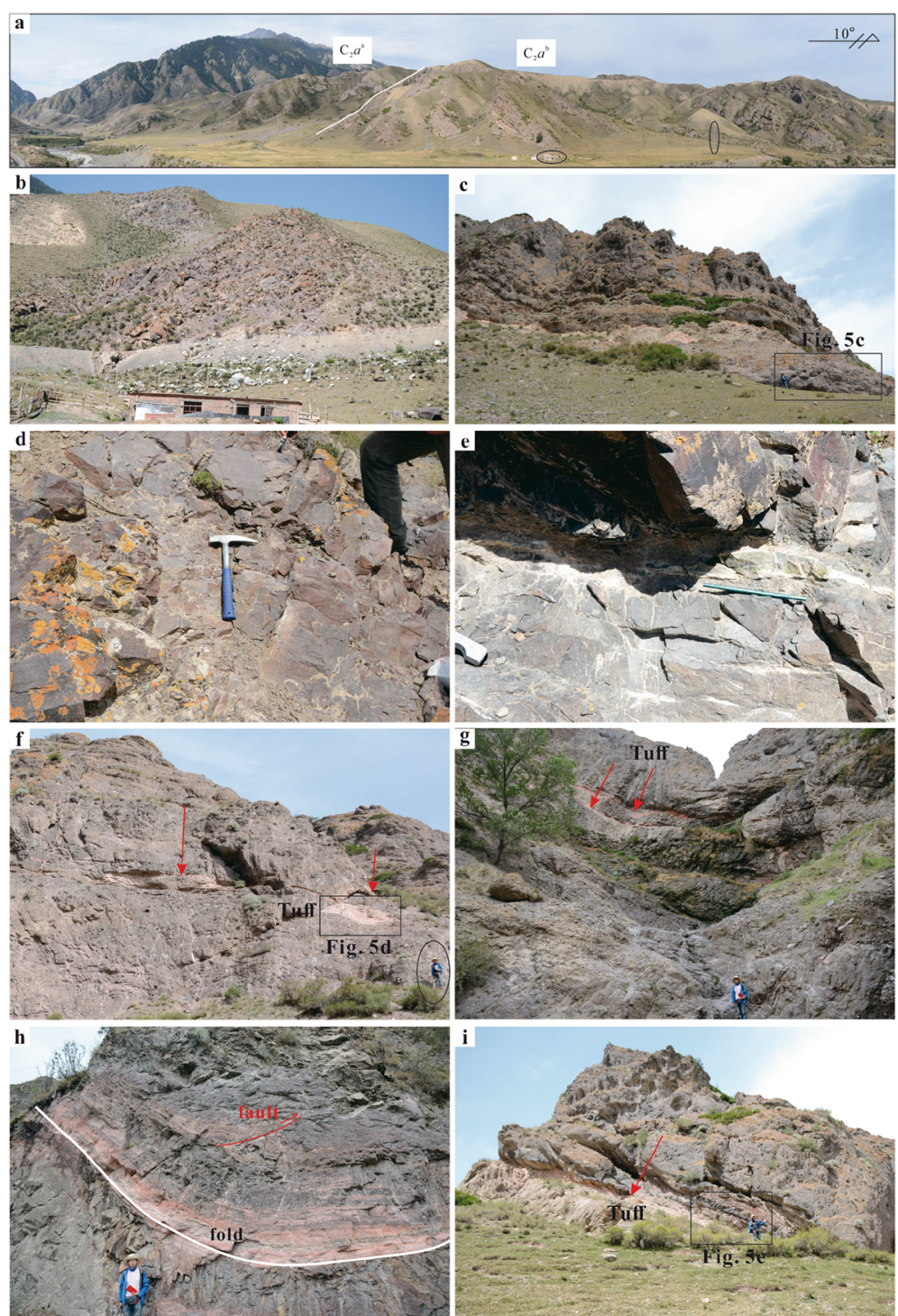

Fig. 4 Field photographs of the Arbasay Formation. a Panoramic photos of the Arbasay Formation; telegraph pole is $10 \mathrm{~m}$ high. $\mathbf{b}$ General characteristics of the lower part of Arbasay Formation. c General characteristics of the upper part of Arbasay Formation. d Claretcolored andesite, Lower Arbasay Formation, hammer $(28 \mathrm{~cm}$ long) shows the scale. e Greyish-green basalts, Lower Arbasay Formation, pencil is $20 \mathrm{~cm}$ (scale) long. $\mathbf{f}-\mathbf{i}$ The tuffs intercalated with the volcanic and volcaniclastic rocks; Upper Arbasay Formation, person (scale) is $1.7 \mathrm{~m}$ tall

volcanic rocks and tuffs (Table 1). The different types of volcanic rocks (andesite, dacite and rhyolite) of the Arbasay Formation reflected the volcanism of the Late Carboniferous (308-305 Ma; Fig. 8a). However, the age of the volcaniclastic rocks in the upper part remains controversial, which led to the uncertainties of the age of Arbasay Formation. In order to further confirm the age of Arbasay Formation, four volcaniclastic rocks (two tuffs and two tuffaceous sandstones) were collected for zircon LA-ICPMS U-Pb dating. Two tuffaceous sandstone samples, Sample 15JG-09 and Sample 15JG-18, show similar unimodal peaks at $308 \mathrm{Ma}$, pointing to one single source.
Combination of nearly automorphic crystal fragments, angular detritus, and principally andesitic volcanic fragments (Fig. 5) implies that the contemporaneous Arbasay volcanic rocks (ca. $308 \mathrm{Ma}$; Fig. 8b) are likely the principal provenance for these two tuffaceous sandstone beds. Moreover, the pyroclastic flow deposits are also developed and interlayered with the volcaniclastic rocks (Fig. 5). This means that sandstones and volcaniclastic rocks of the Arbasay Formation were likely deposited during the syn-sedimentary processes. The minimum age group of the detrital zircons from Sample 15JG-09 and Sample 15JG-18 are $308 \pm 2 \mathrm{Ma}$ and $309 \pm 3 \mathrm{Ma}$, respectively, 

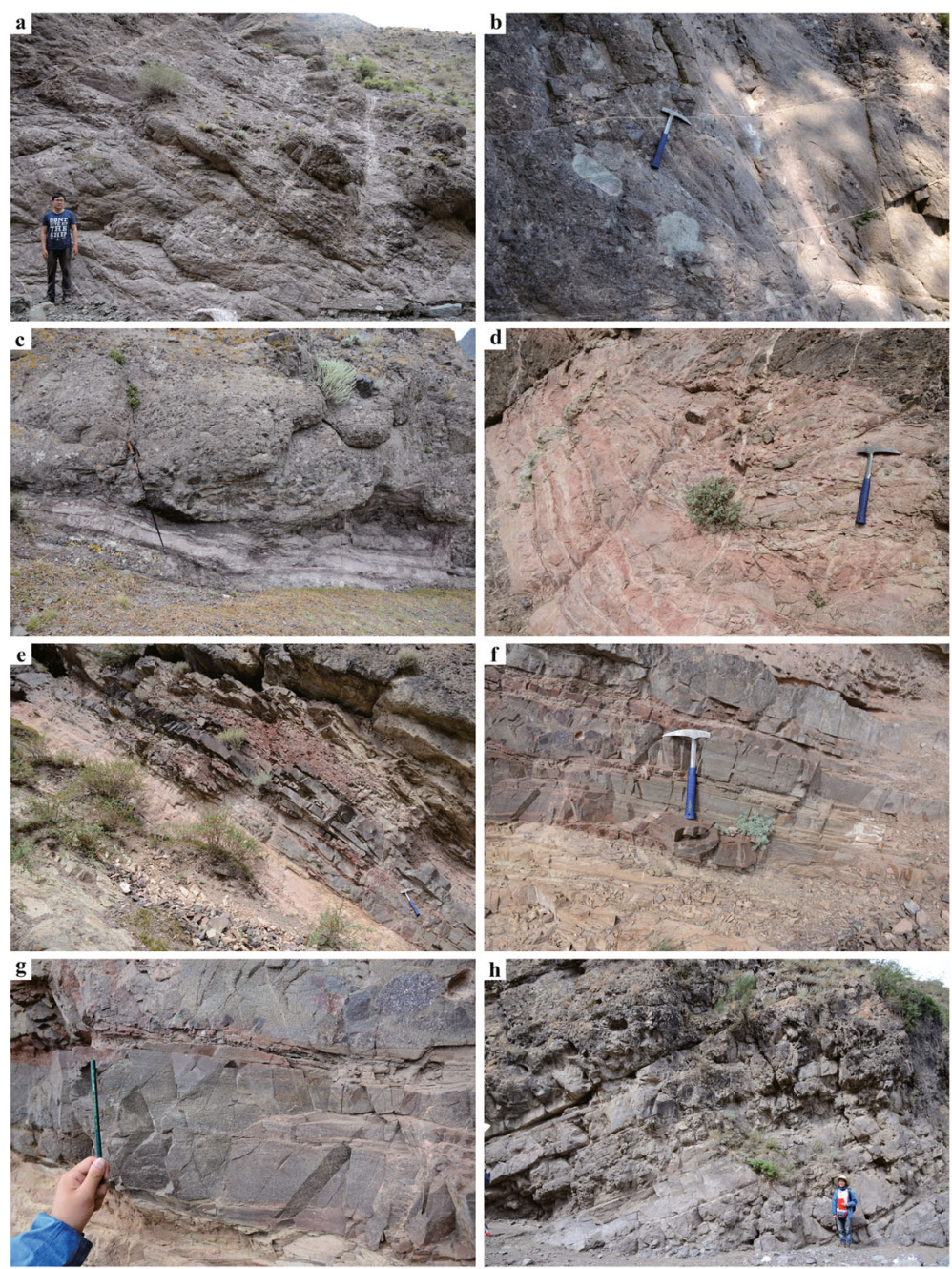

Fig. 5 Representative photographs of volcaniclastic rocks in the upper part of Arbasay Formation. a-c Greyish volcanic breccia and agglomerate; hammer (scale) is $28 \mathrm{~cm}$ long, person (scale) is $1.7 \mathrm{~m}$ tall, alpenstock (scale) is $1 \mathrm{~m}$ long. $\mathbf{d}$ Pink tuff, the deformation is caused by faults and folds; hammer (scale) is $28 \mathrm{~cm}$ long. $\mathbf{e}-\mathbf{g}$ Greyish brown tuffaceous sandstone with cross beddings; pencil (scale) is $20 \mathrm{~cm}$ long. $\mathbf{h}$ Volcaniclastic rocks are conformable contact with each other; person (scale) is $1.7 \mathrm{~m}$ tall

indicating that their sedimentary ages should be younger than $308 \mathrm{Ma}$ (Fig. 8b; Gehrels 2014).

In addition, two tuffs samples were analyzed to further constrain the age of the Arbasay Formation in the studied interval. These quickly deposited tuffs (tephra layers) are regionally compared (Fig. 4). Thus, the tephra layers are excellent key horizons for dating of associated non-volcanic sedimentary sequences (Manville et al. 2009). Sample 15JG-14 from the upper part of Arbasay Formation clustered around two groups $(315 \pm 3 \mathrm{Ma}$ and $304 \pm 2 \mathrm{Ma}$ ). As the tuffs not only appear before the eruption ("pre-eruptive" units), but also after the eruption ("post-eruptive" units), the older age of $315 \pm$ $3 \mathrm{Ma}$ therefore is interpreted to represent the commencing timing of the Arbasay volcanism, and the younger age of $304 \pm 2 \mathrm{Ma}$ for the demise time of the phreatomagmatic activity (Manville et al. 2009; Ross et al. 2005; White et al. 2009). The Arbasay Formation therefore was likely deposited from $315 \mathrm{Ma}$ to $304 \mathrm{Ma}$ after excluding the influence of the inherited zircons. Furthermore, the tuff (Sample 15JG-28) of the upper part of the Arbasay Formation gave a weighted mean age of $310 \pm$ $3 \mathrm{Ma}$ when the inherited zircon ages are irrespective. This age correlates well with the major volcanism of the Arbasay Formation ("syn-eruptive" units), which again suggested that their peak volcanism occurred during the Late Carboniferous (310-307 Ma; Fig. 8c). Stratigraphically, the tuffs conformably contact the volcanic rocks and volcaniclastic rocks (Fig. 2b, c), which are interlayered with the volcanic agglomerate, volcanic breccia, 

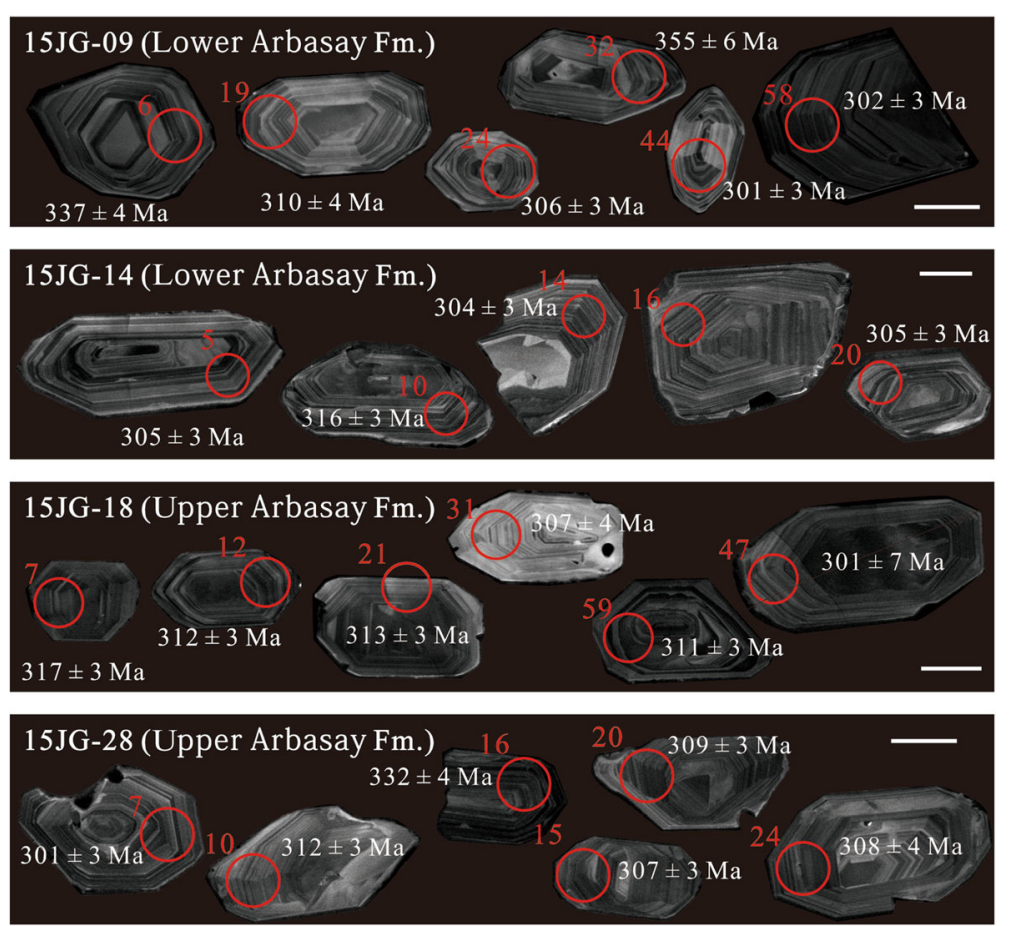

Fig. 6 Cathodoluminescence (CL) images of zircons separated from 15JG-09, 15JG-14, 15JG-18 and 15JG-28. Scale bar in each photomicrograph is $50 \mu \mathrm{m}$ long

tuffaceous sandstone, and basalt (Fig. 4f-i). Therefore, the age of the tuff can represent the depositional age of the volcaniclastic rock, and further constrains the age of basalt, i.e., the basalt was also erupted during the Late Carboniferous.

Clearly, the volcanism indicated by various types of volcanic rocks primarily took place in ca. $308 \mathrm{Ma}$ (Fig. 8a). Zircon $\mathrm{U}-\mathrm{Pb}$ dating analyses of the sandstone samples suggest that the volcaniclastic rocks were likely formed by the syn-sedimentary volcanism (Fig. 8a, b). The age distributions of tuffs constrained that volcanism took place between 315 and $304 \mathrm{Ma}$, and the major explosion occurred in ca. $307 \mathrm{Ma}$ (Figs. 7 and 8c). Our results, in combination with the published data, indicate that the Arbasay Formation in the Shichang Region was deposited during the Late Carboniferous (Fig. 8d).

\subsection{Comparisons with coeval deposits in the Toksun-Turpan Region}

The Arbasay Formation was first established in the Baiyanggou area of Shichang Region, North Tianshan (BGMRXUAR 1999), Xinjiang, northwestern China. Later, a series of volcanic-sedimentary rocks of the Upper Carboniferous Miulintuokaitaoshan Formation (BGMRXUAR 1993) in the Toksun-Turpan Region were re-assigned to the Arbasay Formation (BGMRXUAR 1999) as well. However, the 'Arbasay Formation' in the Toksun-Turpan Region is obviously different from that exposed at its stratotype area in rock types, geochemical characteristics and depositional environment ( $\mathrm{Gu}$ et al. 2000, 2001; Liang et al. 2011; Wang et al. 2017). Firstly, the rock types in the Shichang Region are dominated by andesite with some interbeds of basalts and rhyolites (Figs. 2b, c and 3). However, the rock types in the Toksun-Turpan Region comprise of volcanic-clasticcarbonate rock association, and the volcanic rock is different from other rocks in having bimodal volcanic with minor constituents of dacite and rare andesitic rock (Liang et al. 2011). Secondly, the volcanic rock in the Shichang Region belongs to the calc-alkaline series and shows arc-like geochemical composition (Liu et al. 2012; Wang et al. 2017). In contrast, the volcanic rock in the Toksun-Turpan Region is moderately enriched in incompatible elements, which is assigned to the alkaline and tholeiite series, showing rift-related geochemical characteristic (Gu et al. 2000, 2001; Liang et al. 2011). Thirdly, the depositional environments of volcaniclastics from these two regions are also different. The Arbasay Formation in the Shichang Region is interpreted to be deposited in continental alluvial fan setting (Liu et al. 2015), while the Arbasay Formation in the Toksun-Turpan Region was marine delta and littoral zone formed probably due to the Bogda Rift during the Late Carboniferous (Gu et al. 2000, 2001; Guo et al. 2014; Jiang et al. 2015; Liang et al. 2011). Moreover, the Arbasay Formation volcanic rock in the Shichang Region is typical of continental volcanic 

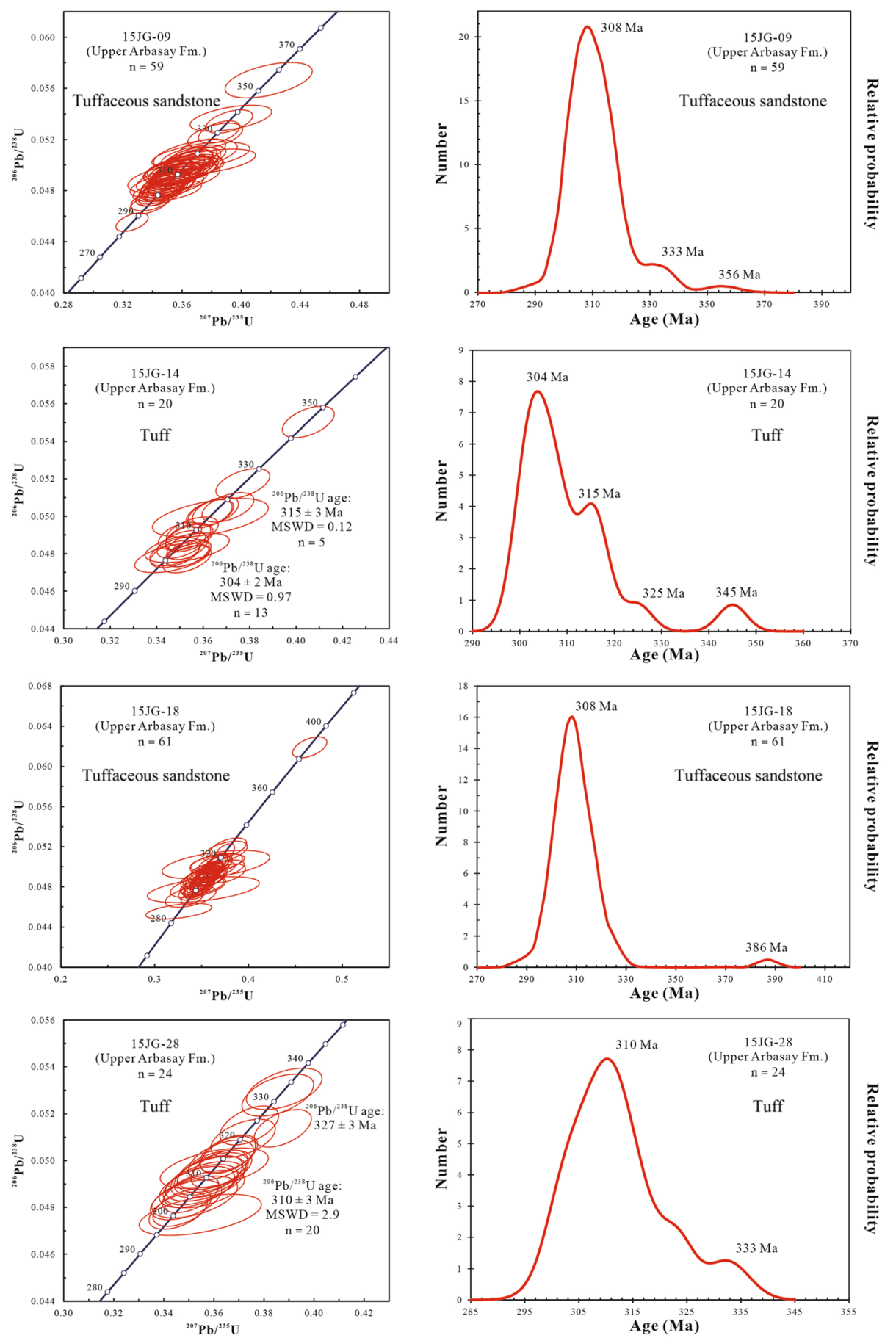

Fig. 7 Zircon U-Pb Concordia and age spectrum diagrams for the four samples

origin (BGMRXUAR 1999; Liu et al. 2015), whereas the same rock in the Toksun-Turpan Region is of marine volcanics sources (Wang 1988; Gu et al. 2000). On the contrary, the volcanic-clastic-carbonate rock association exposed in the Toksun-Turpan Region show high similarity to those of the Aoertu Formation that was established in
Urumqi region (Wang 1988) in terms of lithologic and geochemical features.

Accordingly, the "Arbasay Formation" in both ToksunTurpan and Shichang Regions is lithologically different from one another. The Upper Carboniferous volcanics, clastics, and carbonates of the Toksun-Turpan Region are 



Fig. $8{ }^{206} \mathrm{~Pb} / 238 \mathrm{U}$ age spectrum of the a volcanic rocks, b tuffaceous sandstones, $\mathbf{c}$ tuffs and $\mathbf{d}$ all the samples. Data are from Liu et al. (2012, 2015); Wang et al. (2017) and this text

better assigned to the Aoertu Formation (Wang 1988) than to the Arbasay Formation. The latter unit name is remained to the volcanic-sedimentary rocks in the Shichang Region.

\subsection{Implications for the closure timing of the Junggar-Balkhash Ocean}

Both geochemical features and tectonic inference suggest that the North Tianshan island arc was likely generated by southward subduction of the Junggar-Balkhash oceanic lithosphere and may represent the collision of the Junggar and Central Tianshan Blocks (Han et al. 2010; Windley et al. 2007; Xiao et al. 2008). However, as aforementioned, the timing for the last consolidation was calibrated to Devonian to Permian. The depositional period of the Arbasay Formation is crucial in confirming the timing for the last closure of the Junggar-Balkhash Ocean (Wang et al. 2017a). On the one hand, the Arbasay Formation was interpreted as the result of sedimentation of a continental arc during the transition stage from tectonic compression to extension (Wang et al. 2017), implying that

Table 1 Lithologies, locations and geochronological data of the Arbasay Formation in the Shichang Region, North Tianshan, NW China

\begin{tabular}{|c|c|c|c|c|c|c|}
\hline Samples & Location & Lithologies & Age (Ma) & Methods $^{a}$ & GPS locations & References \\
\hline 15JG-09 & Jingou River & Tuffaeous sandstone & 308 & LA-ICP-MS & $43^{\circ} 54^{\prime} 6^{\prime \prime} N, 85^{\circ} 23^{\prime} 47^{\prime \prime} E$ & This paper \\
\hline 15JG-14 & Jingou River & Tuff & $\begin{array}{l}304 \pm 2 \\
315 \pm 3\end{array}$ & LA-ICP-MS & $43^{\circ} 54^{\prime} 26^{\prime \prime} \mathrm{N}, 85^{\circ} 23^{\prime} 50^{\prime \prime} \mathrm{E}$ & This paper \\
\hline 15JG-18 & Jingou River & Tuffaeous sandstone & 308 & LA-ICP-MS & $43^{\circ} 54^{\prime} 33^{\prime \prime} \mathrm{N}, 85^{\circ} 23^{\prime} 59^{\prime \prime} \mathrm{E}$ & This paper \\
\hline 15JG-28 & Jingou River & Tuff & $310 \pm 3$ & LA-ICP-MS & $43^{\circ} 55^{\prime} 7^{\prime \prime} \mathrm{N}, 85^{\circ} 24^{\prime} 50^{\prime \prime} \mathrm{E}$ & This paper \\
\hline$J G 01$ & Jingou River & Rhyolite & $308 \pm 5$ & LA-ICP-MS & $43^{\circ} 53^{\prime} 45^{\prime \prime} \mathrm{N}, 85^{\circ} 23^{\prime} 39^{\prime \prime} \mathrm{E}$ & Wang et al. 2017 \\
\hline$J G 02$ & Jingou River & Dacite & $305 \pm 4$ & LA-ICP-MS & $43^{\circ} 53^{\prime} 46^{\prime \prime} \mathrm{N}, 85^{\circ} 23^{\prime} 40^{\prime \prime} \mathrm{E}$ & Wang et al. 2017 \\
\hline$J G 07$ & Jingou River & Andesite & $308 \pm 4$ & LA-ICP-MS & $43^{\circ} 54^{\prime} 07^{\prime \prime} \mathrm{N}, 85^{\circ} 23^{\prime} 54^{\prime \prime} \mathrm{E}$ & Wang et al. 2017 \\
\hline TS09-9 & Jingou River & Rhyolite & $307.2 \pm 1.3$ & SHRIMP & & Liu et al. 2012 \\
\hline XJ10-04 & Jingou River & Tuff & $314.4 \pm 3.4$ & LA-ICP-MS & & Liu et al. 2015 \\
\hline
\end{tabular}

${ }^{\mathrm{a}} \mathrm{LA}-\mathrm{ICP}-\mathrm{MS}$, laser ICP-MS single-grain zircon U-Pb age; SHRIMP, sensitive high-resolution ion microprobe zircon $\mathrm{U}-\mathrm{Pb}$ age 
the Junggar-Balkhash oceanic lithosphere continuously subducted until the Late Carboniferous (Wang et al. 2017). On the other hand, the Permian alkaline igneous rocks and A-type granitoids were regarded as the post-collisional products (Ge et al. 2015; Han et al. 2010; Tang et al. 2010; Wang et al. 2009). Moreover, the Early Permian Taoxigou Group in the Aiweiergou area represents the first conglomerate unit since ebb of marine sediments in the Tianshan tectonic complex (Chen et al. 2015). As a result, the deposition of the Arbasay Formation marks the last closure of the Junggar-Balkhash Ocean during the Late Carboniferous.

\section{Conclusions}

Regional geological characteristics, LA-ICP-MS and SHRIMP zircon $\mathrm{U}-\mathrm{Pb}$ dating on the volcanic and volcaniclastic rocks of the Arbasay Formation suggested the age of the Arbasay Formation in the Shichang Region should be redefined as the Late Carboniferous, which marks that the last closure time of the Junggar-Balkhash Ocean was Late Carboniferous. In contrast, the previously called "Arbasay Formation" in the Toksun-Turpan Region should be better assigned to the Aoertu Formation.

\section{Additional file}

Additional file 1: Analytical zircon $\mathrm{U}-\mathrm{Pb}$ data and calculated apparent ages. (XLSX $651 \mathrm{~kb}$ )

\section{Acknowledgements}

We thank Editor-in-Chief Prof. Zeng-Zhao Feng, three reviewers (Prof. Zhong-Qiang Chen, Prof. Bo Wang, Dr. Hao Yang), Editor Yuan Wang and Editor Xiu-Fang Hu for their constructive comments and meticulous corrections which improved the quality of the original manuscript. The authors are also grateful to Dr. Zhuang Li, Dr. Wei Tian and Dr. Qingyun Li for critical comments and helpful suggestions. This study was supported by the National Science and Technology Major Project of China (Grant No. 2017ZX05008-001).

\section{Authors' contributions}

$J$ LW carried out the zircon U-Pb dating studies, participated in the field geological investigation and drafted the manuscript. CDW participated in the field geological investigation and drafted the manuscript. XJ, WZ and JW carried out the zircon U-Pb dating studies and modified the manuscript. JW and MLZ conceived of the study and participated in its design and coordination. All authors read and approved the final manuscript.

\section{Competing interests}

The authors declare that they have no competing interests.

\section{Publisher's Note}

Springer Nature remains neutral with regard to jurisdictional claims in published maps and institutional affiliations.

\footnotetext{
Author details

${ }^{1}$ Key Laboratory of Orogenic Belts and Crustal Evolution, Ministry of Education, School of Earth and Space Sciences, Peking University, Beijing 100871, China. ${ }^{2}$ Institute of Oil \& Gas, Peking University, Beijing 100871, China. ${ }^{3}$ Department of Xinjiang Exploration Project Management, Sinopec Shengli Oilfield Company, Dongying 257000, Shandong, China. ${ }^{4}$ Research Institute of Exploration and Development, Xinjiang Oilfield Company, PetroChina, Karamay 834000, Xinjiang, China.
}

Received: 29 September 2017 Accepted: 8 January 2018

Published online: 02 August 2018

\section{References}

Andersen, T. 2002. Correction of common lead in U-Pb analyses that do not report ${ }^{204} \mathrm{~Pb}$. Chemical Geology 192: 59-79.

BGMRXUAR (Bureau of Geology and Mineral Resources of Xinjiang Uygur Autonomous Region). 1993. Regional geology of Xinjiang Uygur autonomous region. Beijing: Geological Publishing House (in Chinese).

BGMRXUAR (Bureau of Geology and Mineral Resources of Xinjiang Uygur Autonomous Region). 1999. Lithostratigraphy of Xinjiang Uygur autonomous region, 96. Wuhan: China University of Geosciences Press (in Chinese).

Bykadorov, V.A., V.A. Bush, O.A. Fedorenko, I.B. Filippova, N.V. Miletenko, V.N. Puchkov, A.V. Smirnov, B.S. Uzhkenov, and Y.A. Volozh. 2003. Ordovician-Permian palaeogeography of Central Eurasia: development of Palaeozoic petroleum-bearing basins. Journal of Petroleum Geology 26 (3): 325-350.

Carroll, A.R., S.A. Graham, M.S. Hendrix, D. Ying, and D. Zhou. 1995. Late Paleozoic tectonic amalgamation of Northwestern China: sedimentary record of the Northern Tarim, Northwestern Turpan, and Southern Junggar Basins. Geological Society of America Bulletin 107: 571-594.

Charvet, J., L.S. Shu, and S. Laurent-Charvet. 2007. Paleozoic structural and geodynamic evolution of eastern Tianshan (NW China): welding of the Tarim and Junggar plates. Episodes 30: 162-186.

Charvet, J., L.S. Shu, S. Laurent-Charvet, B. Wang, F. Michel, C. Dominique, Y. Chen, and D.J. Koen. 2011. Paleozoic tectonic evolution of the Tianshan belt, NW China. Science China Earth Sciences 54: 166-184.

Chen, Z.Q., Z.T. Liao, and L.J. Liu. 2015. Correction of two upper Paleozoic stratigraphic units in the Tianshan Mountains region, Xinjiang Uygur autonomous region and implications on the late Paleozoic evolution of Tianshan tectonic complex, Northwest China. Journal of Palaeogeography 4: 358-370.

Chen, Z.Q., and G.R. Shi. 2003. Late Paleozoic depositional history of the Tarim basin, Northwest China: an integration of biostratigraphic and lithostratigraphic constraints. AAPG Bulletin 87: 1323-1135.

Corfu, F., J.M. Hanchar, P.W.O. Hoskin, and P. Kinny. 2003. Atlas of zircon textures. Reviews in Mineralogy and Geochemistry 53: 469-500.

Filippova, I.B., V.A. Bush, and A.N. Didenko. 2001. Middle Paleozoic subduction belts: the leading factor in the formation of the Central Asian fold-and-thrust belt. Russian Journal of Earth Sciences 3 (6): 405-426.

Gao, J., G.Q. He, M.S. Li, X.C. Xiao, Y.Q. Tang, J. Wang, and M. Zhao. 1995. The mineralogy, petrology, metamorphic PTDt trajectory and exhumation mechanism of blueschists, South Tianshan, Northwestern China. Tectonophysics 250: 151-168.

Gao, J., M.S. Li, X.C. Xiao, Y.Q. Tang, and G.Q. He. 1998. Paleozoic tectonic evolution of the TianshanOrogen, Northwestern China. Tectonophysics 287: 213-231.

Ge, S.S., M.G. Zhai, I. Safonova, D.P. Li, X.Y. Zhu, P.F. Zuo, and H.X. Shan. 2015. Whole-rock geochemistry and $\mathrm{Sr}-\mathrm{Nd}-\mathrm{Pb}$ isotope systematics of the late carboniferous volcanic rocks of the Awulalemetallogenic belt in the Western Tianshan Mountains (NWChina): petrogenesis and geodynamical implications. Lithos 228-229: 62-77.

Gehrels, G. 2014. Detrital zircon U-Pb geochronology applied to tectonics. Annual Review of Earth and Planetary Sciences 42: 127-149.

Gu, L.X., S.X. Hu, C.S. Yu, H.Y. Li, J.X. Xiao, and Z.F. Yan. 2000. Carboniferous volcanites in the Bogda orogenic belt of eastern Tianshan: their tectonic implications. Acta Petrologica Sinica 16: 305-316 (in Chinese with English abstract).

Gu, L.X., S.X. Hu, C.S. Yu, C.Z. Wu, and Z.F. Yan. 2001. Initiation and evolution of the Bogda subduction-torn-type rift. Acta Petrologica Sinica 17: 585-597 (in Chinese with English abstract).

Guo, L.N., Y. Li, C.Q. Su, L. Xiao, and J.R. Zhou. 2014. The sedimentary facies characteristics and significance of Aoertu formation, Dezhetalede, Qijiaojing Town, Xinjiang. Xinjiang Geology 32: 48-52 (in Chinese with English abstract).

Han, B., S. Wang, B.-M. Jahn, D. Hong, H. Kagami, and Y. Sun. 1997. Depletedmantle source for the Ulungur River A-type granites from North Xinjiang, China: Geochemistry and $\mathrm{Nd}-\mathrm{Sr}$ isotopic evidence, and implications for Phanerozoic crustal growth. Chemical Geology 138: 135-159.

Han, B.F., Z.J. Guo, Z.C. Zhang, L. Zhang, J.F. Chen, and B. Song. 2010. Age, geochemistry, and tectonic implications of a late Paleozoic stitching pluton in the North Tian Shan suture zone, Western China. Geological Society of America Bulletin 122: 627-640. 
Han, B.F., G.Q. He, X.C. Wang, and Z.J. Guo. 2011. Late carboniferous collision between the Tarim and Kazakhstan-Yili terranes in the western segment of the South Tian Shan Orogen, Central Asia, and implications for the Northern Xinjiang, Western China. Earth-Science Reviews 109: 74-93.

Jiang, S.H., S.Z. Li, I.D. Somerville, J.P. Lei, and H.Y. Yang. 2015. CarboniferousPermian tectonic evolution and sedimentation of the Turpan-Hami Basin, NW China: Implications for the closure of the Paleo-Asian Ocean. Journal of Asian Earth Sciences 113: 644-655.

Korobkin, V.V., and M.M. Buslov. 2011. Tectonics and geodynamics of the western central Asian Fold Belt (Kazakhstan Paleozoides). Russian Geology and Geophysics 52: 1600-1618

Liang, T., X.C. Guo, J.G. Guo, T.B. Fan, H.F. Qin, R.H. Zhou, and H. Hei. 2011. Geochemistry and structure characteristic of carboniferous volcanic rocks in the eastern of Bogeda Mountain. Xinjiang Geology 29: 289-295 (in Chinese with English abstract).

Liu, D.D., F. Cheng, Z.J. Guo, M. Jolivet, and Y. Song. 2015. Lahar facies of the latest Paleozoic Arbasay formation: Geomorphological characters and paleoenvironment reconstruction of Northern Tian Shan, NW China. Journal of Asian Earth Sciences 113: 282-292.

Liu, D.D., Z.J. Guo, Z.C. Zhang, and C.D. Wu. 2012. The late Paleozoic tectonic relationship between the Tian Shan orogenic belt and Junggar basin: Constraints from zircon SHRIMP U-Pb dating and geochemistry characteristics of volcanic rocks in Arbasay formation. Acta Petrologica Sinica 28: 2355-2368 (in Chinese with English abstract).

Ludwig, K.R. 2003. ISOPLOT 3: A geochronological toolkit for Microsoft excel, 1-74. Berkeley: Berkeley Geochronology Centre Special Publication.

Manville, V., K. Németh, and K. Kano. 2009. Source to sink: A review of three decades of progress in the understanding of volcaniclastic processes, deposits, and hazards. Sedimentary Geology 220: 136-161.

Ross, P.S., I.U. Peate, M.K. McClintock, Y.G. Xu, I.P. Skilling, J.D.L. White, and B.F. Houghton. 2005. Mafic volcaniclastic deposits in flood basalt provinces: a review. Journal of Volcanology and Geothermal Research 145: 281-314.

Su, C.Q., Y.J. Sun, X.K. Yang, and A.D. Xu. 2006a. Definition of some unconformities in the late Paleozoic-Mesozoic system in the Houxia-Ewirgol area, Tianshan Mountains, and its geological significance. Geological Bulletin of China 25: 977-985 (in Chinese with English abstract).

Su, C.Q., X.K. Yang, J.J. Cui, and J.Q. Liu. 2006b. Redefinition of the DevonianPermian in the Tengger Mountain-Ewirgol area, eastern segment of the West Tianshan Mountains, and its geological significance. Geology in China 33: 516-528 (in Chinese with English abstract).

Tang, G.J., Q. Wang, D.A. Wyman, M. Sun, Z.X. Li, Z.H. Zhao, W.D. Sun, X.H. Jia, and Z.Q. Jiang. 2010. Geochronology and geochemistry of late Paleozoic magmatic rocks in the Lamasu-Dabate area, northwestern Tianshan (West China): Evidence for a tectonic transition from arc to post-collisional setting. Lithos 119: 393-411.

Wang, B., D. Cluzel, L.S. Shu, M. Faure, J. Charvet, Y. Chen, S. Meffre, and K. Jong. 2009. Evolution of calc-alkaline to alkaline magmatism through carboniferous convergence to Permian transcurrent tectonics, western Chinese Tianshan. International Journal of Earth Sciences 98: 1275-1298.

Wang, B., M. Faure, L.S. Shu, K. Jong, J. Charvet, D. Cluzel, B.-M. Jahn, Y. Chen, and G. Ruffet. 2010. Structural and geochronological study of high-pressure metamorphic rocks in the Kekesu section (Northwestern China): implications for the late Paleozoic tectonics of the Southern Tianshan. The Journal of Geology 118: 59-77.

Wang, B., L.S. Shu, D. Cluzel, M. Faure, and J. Charvet. 2007. Geochemical constraints on carboniferous volcanic rocks of the Yili Block (Xinjiang, NW China): Implication for the tectonic evolution of Western Tianshan. Journal of Asian Earth Sciences 29: 148-159.

Wang, B.Y. 1988. The division of the middle-late carboniferous strata in the Urumqi, Xinjiang. Journal of Stratigraphy 12: 20-27 (in Chinese with English abstract)

Wang, J.L., C.D. Wu, Z. Li, W. Zhu, Y.W. Chen, Q.Y. Li, J. Wu, L.J. Deng, and R. Chen. 2017. Geochronology and geochemistry of volcanic rocks in the Arbasay formation, Xinjiang Province (Northwest China): Implications for the tectonic evolution of the North Tianshan. International Geology Review 59 (10): 1324-1343.

Wang, J.L., C.D. Wu, Z. Li, W. Zhu, T.Q. Zhou, J. Wu, and J. Wang. 2018. The tectonic evolution of the Bogda region from Late carboniferous to Triassic time: evidence from detrital zircon U-Pb geochronology and sandstone petrography. Geological Magazine 155 (5): 1063-1088. https:// doi.org/10.1017/S0016756816001217.
Wang, J.L., C.D. Wu, W. Zhu, Z. Li, J. Wu, R. Chen, and J. Wang. 2016. Tectonicdepositional environment and prototype basin evolution of the PermianTriassic in the southern Junggar Basin. Journal of Palaeogeography (Chinese Edition) 18: 643-660 (in Chinese with English abstract).

White, J.D.L., S.E. Bryan, P.S. Ross, S. Self, and T. Thordarson. 2009. Physical volcanology of continental large igneous provinces: Update and review. In Studies in volcanology: the legacy of George Walker, ed. T. Thordarson, S. Self, G. Larsen, S.K. Rowland, and A. Hoskuldsson, vol. 2, 291-321. London: Special Publications of IAVCEI, Geological Society of London.

Windley, B.F., D. Alexeiev, W.J. Xiao, A. Kröner, and G. Badarch. 2007. Tectonic models for accretion of the Central Asian Orogenic Belt. Journal of the Geological Society of London 164: 31-47.

Xiao, W.J., C.M. Han, C. Yuan, M. Sun, S.F. Lin, H.L. Chen, Z.L. Li, J.L. Li, and S. Sun 2008. Middle Cambrian to Permian subduction-related accretionary orogenesis of Northern Xinjiang, NW China: Implications for the tectonic evolution of Central Asia. Journal of Asian Earth Sciences 32: 102-117.

Xu, X.Y., X.M. Li, Z.P. Ma, L.Q. Xia, Z.C. Xia, and S.X. Peng. 2006. LA-ICP-MS zircon $\mathrm{U}-\mathrm{Pb}$ dating of gabbro from the Bayingou ophiolite in the Northern Tianshan Mountains. Acta Geologica Sinica 80: 1168-1176 (in Chinese with English abstract).

Xu, X.Y., Z.P. Ma, L.Q. Xia, Y.B. Wang, X.M. Li, Z.C. Xia, and L.S. Wang. 2005 SHRIMP dating of the plagiogranite from Bayingou ophiolite in the Northern Tianshan Mountains. Geological Review 51: 523-527 (in Chinese with English abstract).

Yang, W., M. Jolivet, G. Dupont-Nivet, Z.J. Guo, Z.C. Zhang, and C.D. Wu. 2013. Source to sink relations between the Tian Shan and Junggar basin (Northwest China) from late Palaeozoic to quaternary: evidence from detrital U-Pb zircon geochronology. Basin Research 24: 1-22.

Yang, X.K., C.Q. Su, H. Chen, H.J. Zhang, H.Q. Yan, X.F. Li, and J.Q. Liu. 2006 Discovery of the Permian volcanic rocks in the Bingdaban-Houxia, Tianshan Mountains, and its geological significance. Geological Bulletin of China 25: 969-976 (in Chinese with English abstract).

Yuan, H.L., S. Gao, X.M. Liu, H.M. Li, D. Günther, and F.Z. Wu. 2004. Accurate U-Pb age and trace element determinations of zircon by laser ablation inductively coupled plasma mass spectrometry. Geostandard Newslettr 28: 353-370.

Zhang, X., J.Q. Tian, J. Gao, R. Klemd, L.H. Dong, J.J. Fan, T. Jiang, C.J. Hu, and Q. Qian. 2012. Geochronology and geochemistry of granitoid rocks from the Zhibo syngenetic volcanogenic iron ore deposit in the Western Tianshan Mountains (NW-China): Constraints on the age of mineralization and tectonic setting. Gondwana Research 22: 585-596.

\section{Submit your manuscript to a SpringerOpen ${ }^{\odot}$ journal and benefit from:}

- Convenient online submission

- Rigorous peer review

- Open access: articles freely available online

- High visibility within the field

- Retaining the copyright to your article

Submit your next manuscript at $>$ springeropen.com 